\title{
Temporalities of Mental Health Recovery
}

\section{Abstract}

Since the 1990s, the concept of "recovery in/from serious mental health problems" has been iterated internationally as the new paradigm in mental health policy and practice. A constitutive element of recovery discourse is a struggle over what defines a "good" life-in-time, yet temporalities of recovery remain under-investigated. This paper offers an empirical exploration of recovery enacted in an NHS "arts for mental health" service called Create. I present an analysis of several intersecting temporalities at play within Create through the lens of one service-user's story. The temporal orderings of the situated aesthetic care practices at Create encapsulate competing articulations of recovery, hope, and aspiration. These different temporalities enact different subjectivities, revealing recovery to be a set of socio-political struggles over what lives are deemed liveable in the context of global neoliberal capitalism.

Keywords: subjectivity; temporality; mental health recovery; mental health practices; refugees; neoliberalism.

\section{Introduction}

The concept of recovery articulates struggles over practice, expertise and evidence in mental healthcare. It is thought to have been first proposed in 1970s by mental health activists seeking to contest psychiatric power (see Deegan, 1994; Frese and Davis, 1997; Repper and Perkins, 2003; Turner-Crowson and Wallcraft, 2002)..$^{1}$ These activists claimed it was possible to recover from experiences of madness and distress without psychiatric intervention. They advocated for peer-run services (Chamberlin, [1977] 1988) and human rights for mental patients (Frese and Davis, 1997). From the 1990s onwards, "recovery" gained prominence becoming a central feature of mental health 
policies in many countries (Slade et al., 2008). It is now described as an international "buzzword" or paradigm in mental health (for example Bracken and Thomas, 2006; Clay, 1999; Craig, 2008). In their uptake of recovery, mental health professional propose that recovery-orientated practice should involve collaborative care relationships between patients and practitioners: 'real recovery is done with the person rather than to them' (Champ, 1999, p.144: original emphasis). However, there is increasing disillusionment with recovery implementation amongst service-users/survivors and activists who argue that its social justice principles have been destroyed. They suggest that recovery has been co-opted by biomedical psychiatry and inscribed with neoliberal values that do more harm than good (Howells, A. and Voronka, J., 2012; Morrow, 2013; Poole, 2011).

Recovery 'is a polyvalent concept' (Pilgrim, 2009, p. 475) that elides consensus in its definition. Thus, rather than focussing on what recovery "really is" (or "should be"), I conceptualize recovery as a site of socio-political struggle over what lives are deemed liveable in the context of global neoliberalism. I argue that a key aspect of this struggle is temporal. In doing so, I argue that temporalities and subjectivities can be understood as co-constitutive and aim to contribute to work around 'how subjectivity can effectuate and promote social and political change' (Blackman et al., 2008, p. 16). Vincanne Adams, Michelle Murphy and Adele E. Clarke contend that '[o]ne of the defining qualities of our current moment is its peculiar management of time, or what might be called a politics of temporality' (Adams et al., 2009, p.246). In the global capitalist context, how we know ourselves, act, relate or become with the social world is constituted through particular temporalities that specify how time is or should be passed. The politics of temporality 
matter; the materiality of different temporalities constrain/enable different possibilities for action, agency and change.

In this paper, using data collected at a NHS "arts for mental health" service called Create, ${ }^{2}$ I focus on the concept of "recovery in/from serious mental health problems" and its multiple temporalities. I draw upon the Foucauldian tradition to think about the relations of power implicit in the service's neoliberal practices of temporal subjectification (for example, practices that enact subjects that are regular and on-time). However, I also extend and trouble this approach to 'how subjectivity materializes in the social realm' (Blackman et al., 2008, p. 16) by developing a material-semiotics of temporality (Haraway, 1997). I show that there are competing temporalities of recovery in the practices of Create, from activist reclamations of hope to the neoliberal politics of aspiration to the ongoing rhythms of chatting and art-making. These practices of recovery enact different temporalities, and thus different subjectivities. I show that temporality is not only symbolic but materialized and embodied in ways that both reproduce inequalities and offer the possibility of resistance. I ask if '[s] ubjectivity is always unfinished, partial, non-linear' (Blackman et al., 2008, p. 16), what is the moral economy of neoliberal temporality that privileges 'particular locations, situations and actors' (Adams, et al., 2009, p. 247) and what alternatives are possible?

\section{Methods}

This paper is drawn from ethnographic research conducted at Create, a NHS community mental health service. People categorized as having "severe and enduring mental health problems" attend Create as part of their discharge from in-patient psychiatric facilities. It is a small service comprising six different art studios, each with its own artist-tutor, overseen by a Manager and an Occupational Therapist. Service- 
users attend studio sessions once per week in small groups. The root premise underpinning the service's model of practice is that both learning and creativity improve mental health. The tutors aim to impart life skills and inspire confidence and self-esteem through teaching different techniques of art-making.

The focus of the research was the multiple enactments of recovery and mental health, from policy object to personal process, as they intersect in the local practices of Create. Methods comprised my accessing the service as a service-user would do for six months, and conducting qualitative and semi-structured interviews with six service-users, six staff members. I also conducted a textual analysis of recovery in mental health policy to situate the field data and interviews, paying attention to the interplay between local practices and broader policy and governance contexts.

The research was designed in collaboration with the Service Manager and Occupational Therapist of Create. They wanted to prove that what they do has health outcomes. In the age of Evidence-Based Medicine, they felt increasing pressure to demonstrate their value in the "right terms" for NHS. My research offered a "thick description" of the service and a critical engagement with how their focus on being "evidence-based" might be changing and even reducing their "efficacy". Instead of approaching this as a study of "arts for health" I focussed on the practices of care enacted at Create; aiming to meets care 'in its own terms' (Mol, 2008, p. 2). In doing so, I draw upon a history of research about care and caring coming from disability studies, feminist research and science and technology studies.

Gaining a 'patient's-eye-view' (Sedgwick, 1987, p. 137) through accessing the service as a service-use would do was part of my commitment to a participatory ethnographic approach in which '[y]ou don't exactly penetrate another culture, as the masculinist 
image would have it. You put yourself in its way and it bodies forth and enmeshes you' (Geertz, 1995, p. 44). I paid attention to both those who care and those being cared for, as well as non-human actors present within these care relationships, such as the building, the art materials, the timetables, and diaries that service-users fill in after each session. This perspective reveals care to be aesthetic, relational, situated and materially heterogeneous. The continued concern with attributing effectiveness in mental healthcare over-simplifies the complexity of care within our contemporary multidisciplinary mental health landscape. My research provides an alternative view of the service to the one provided through measuring length of time in the service, or wellbeing, and counting discharge.

\section{Milana's Story}

I begin with the story of one of Create's service-users, a refugee called Milana. Her story brings other contexts than mental healthcare into view. Her story is not exceptional; many refugees experience poor mental health as result of enforced migration. They may be traumatised by what they have experienced in their home country, the fraught journey to the host nation, and/or what they are subjected to on arrival (Faculty of Public Health, 2008). The specificity of Milana's story, her journey to and experience of Create, highlights the politics of temporality. She helps us to understand mental health recovery as socially situated and enacted, in part, through intersecting temporalities. This challenges the idea of recovery as an individual process that can be effected through treatment.

Milana and her husband arrived in Britain in 2003 after fleeing the ongoing conflict in Chechnya. They made a claim for asylum, and during their time waiting to be granted leave to remain the couple were separated and Milana found herself living on her own 
in a bedsit in a suburban district of an English city. ${ }^{3}$ During this separation Milana started hearing voices for the first time, which was a distressing and disorientating development that eventually led to her attempting suicide. ${ }^{4}$ Following this, she was admitted onto a psychiatric ward for nine months. Milana told me that in the time leading up to her hospitalisation she began to paint as a way to express her anguish, confusion and distress: 'I didn't speak because I didn't have anyone to speak to; so, I thought if I draw something, I like to release from my thoughts' (interview 28/09/10). Once on the ward, she enjoyed arts and crafts sessions with the occupational therapists. On discharge, she was referred to Create after she expressed interest in using art to experience enjoyment.

When I met Milana she had been attending Create for around five years. She told me that when she first arrived at the service she was very scared and barely spoke to anybody. She could speak very little English, which confounded matters. However, during her time in the service learning textiles, she discovered that she had a flair for embroidery. She found that the repetitive action of stitching helped to quieten the voices she hears and was therefore very relaxing. Producing beautiful textile pieces also bolstered her confidence. Over time, Milana accrued English speaking skills and found she could communicate more during the sessions, which meant she felt less lonely and isolated. By the time I met Milana, she was studying English at a local college, singing in a choir, and volunteering at a local service for homeless people. She and her husband, now reunited, had been granted leave to remain in Britain as refugees; they had a new home and friends. She continues to live with the enduring phenomenon of hearing voices and no longer wishes to end that life. 


\section{The co-constitution of temporalities and subjectivities}

Eviatar Zerubavel (1982) argues that whilst there are 'an infinite number of temporal reference frameworks' (p. 1) that can be used to quantify time and may work subjectively, social life requires a standardized time that is meaningful to people in general. Standardised time presumes standardized subjects, so that not being able to locate oneself in time by knowing the day, month and year is understood as a symptom of mental illness and/or brain dysfunction. According to Zerubavel (1982), the origins of standardized time can be found in the establishment of new mail delivery systems and rail networks during the industrial revolution in the UK. He argues that the move to standardized time also facilitated the strengthening of global networks. For example, the creation of Greenwich Mean Time came with the laying of international telegraphic cables. In the words of those who made the decision, this was done for " the common good of mankind" calling all delegates to be "citizens of the world"' (Zerubavel, 1982, p. 14). Thus, global capitalist citizenship is enacted through standardized time.

E.P. Thompson (1967) contends that this period of industrialisation and globalisation also instituted a stronger distinction between work and leisure. Time becomes currency that must be spent according to the moral values of that socioeconomic context: 'In mature capitalist society all time must be consumed, marketed, put to use; it is offensive for the labour force merely to "pass the time"' (Thompson, 1967, pp. 90-91). Developing his semiotics of temporality, Zerubavel (1987) also argues that as we spend time it is a form of symbolic currency imbued with certain values. For example, Craig Jeffrey (2008) highlights the implications of the colonial export of standardized, chronological time: 'These various visions of linear time operating at different social and spatial scales commonly exert a symbolic violence on waiting 
populations, who often come to be labelled or label themselves as 'failures' or 'people left behind" (p. 955). Making someone wait is a relationship of power.

\section{Chronicity and the Loss of Hope}

Within this global capitalist complex, Western biomedical psychiatric diagnoses have temporal dimensions. For example, the collection of behaviours brought under the diagnosis of "dementia praecox" (later renamed schizophrenia) were understood to emerge "early" in childhood or teenage years, and to be degenerative, that is, to worsen over time (Jacobson, 2004). Equally, bipolar disorder, once "manic depression," is seen as typified by its cyclical nature - high moods followed by low moods. According to psychiatric classification, these experiences are framed as sicknesses of time: persistent, life-long, and hopeless. Through the language of chronicity they are deemed pathological in their endurance or temporal excess.

User/survivor activists argue that psychiatry's pathologisation of chronicity entails great harm (see Campbell, 1996; Deegan, 1994; Frese and Davis, 1997). According to their own lived experience, psychiatric diagnoses produce a normative temporal subjectivity that reduces agency and prevents recovery. For example, activist Peter Campbell observes, ' $[t]$ he idea of illness, of illness that can never go away, is not a dynamic, liberating force' (1996, p. 57). In this critique, receipt of a psychiatric diagnosis extinguishes a person's hopes and dreams for the future and replaces them with a prospective lifetime of medication and hospitalisation. It is the diagnosis that is pathological not the experiences. ${ }^{6}$

Activist Pat Deegan (1994) describes this temporal wasting in vivid detail:

We experienced time as a betrayer. Time did not heal us. Our pasts deserted us and we could not return to who we had been. Our futures appeared to us to be barren, lifeless places in which no dream could be planted and grow into a reality. As for the 
present, it was a numbing succession of meaningless days and nights in a world which we had no place, no use, and no reason to be. (p. 55: emphasis added)

In Deegan's description she is both a prisoner of 'meaningless days and nights,' and outside of normative time, such as "clock-time" or "work-time"; a victim of a materially and symbolically violent psychiatric diagnostic temporality. To lose one's personal history and sense of future in this way is a consequence of exclusion from a system that sees time as hyper-meaningful and morally imbued. Futures which are 'barren' are unproductive and therefore unplaceable and useless in a capitalist system focussed on (re)production. The use of the word 'barren' by Deegan (1994) also encapsulates the sexist and heternormative character of capitalist life, where discourses of reproduction, future generations and progress can be understood to subjugate the lives of many (Edelman, 2004).

Lisa Blackman has argued that psychiatry invokes a particular form of hope invested in science and technology to 'alleviate suffering and restore the individual to some version of normality' (2007, p. 8). User/survivor activists argue that psychiatric discourse erases hope by deeming some lives "unliveable" without continued medical interventions. They argue that when patients are encouraged or expected to place their hope in biomedical psychiatry they become unable to find their own collective, creative and non-coercive ways to endure experiences of madness and distress. Through the concept of "recovery" user/survivor activists have argued that it is possible to live "a life worth living" without psychiatric intervention. These contrasting claims to hope both politicize the way in which the future is lived in the present. In this way, temporalities of recovery are an important consideration for exploring the materialization of subjectivities and extant inequalities. 


\section{Waiting and Waste}

Like Deegan's experience of psychiatric treatment, Milana's traumatising experience of seeking asylum also entailed meaningless days and nights and barren futures. Since arriving in the UK and up until she began to attend Create, Milana had invariably been made to wait. According to the Refugee Council website:

Since 2005 most people recognised as refugees are only given permission to stay in the UK for five years and can have their case reviewed at any time. This makes it difficult for them to make decisions about their future, to find work and make definite plans for their life in the UK. (Refugee Council, 2013: original emphasis)

Jean-François Bayart (2007, p. 272) has argued that waiting is a 'constitutive practice' of globalisation in which irregular migrants are frequently kept in 'situation[s] of permanent waiting'. Jeffrey (2008) has described such enforced 'chronic waiting' (p. 954) as a peculiarly contemporary form of temporal violence. The British state makes asylum-seekers wait to be granted leave to remain (or not), and this can be traumatising and disabling.

Milana was made not only to wait for leave to remain with its access to most of the rights and responsibilities of citizenship - community, work, education, and so on - but also to be reunited with her husband. She described to me the consequences of being made to wait as 'my mind is not with me - it is somewhere else - I am at home' (interview 21/09/10). Experiencing this loss of mind, Milana began to feel increasingly as if she was a "waste," and she told me that this led to her suicide attempt:

I don't like to live anymore, I thought I am waste because I can't help to husband or my family or anyone, I can't do anything ... so I thought I am like a burden or something for them, so I thought I want to kill myself, so I don't like to live (interview 28/09/10: emphasis added)

Drawing on Zygmund Bauman's work, Imogen Tyler argues that what characterizes global neoliberalism 'is the intensification of human waste-production within the state 
and at its borders by, for example, withholding citizenship from migrants or enforcing poverty on people through diminishing opportunities for welfare, education, or secure forms of work' (2013, p. 47). Similarly, Karen Soldatic argues that in neoliberal workfare regimes, '[d]isabled people's 'workless' status has now become inscribed not only on their bodies, but also within, as they are forced to internalize social practices of morality that situate their bodies and minds as useless and waste' (2013, p. 4: emphasis added). What Milana articulates above is, in part, the lived experience and embodiment of a life wasted both physically and psychologically by the ravages of global capitalism, such as enforced migration (and ensuing family estrangement and/or marital separation). This intersects with the socio-material and gendered practices of neoliberal capitalism that equates disability and worklessness with waste or uselessness, which Milana has clearly internalized. From this perspective, because Milana was unable to participate in normative gendered roles of reproduction (helping her husband or family), and because she was made to wait, she felt that she was wasting time. In turn, this made her feel like she was a waste of time, and therefore a waste of life. Time, life and use-value conflated in complex and moralising ways that diminished Milana's perceived right to her own life. Her story vividly illuminates a material-semiotics of temporality and subjectivity together. I now consider how attending Create helped Milana in her recovery.

\section{The Temporal Organisation of Create}

Over the years, the Create staff members have faced many problems in their practice. They often found themselves undervalued as practitioners in the health service because of the kind of work that they do. In response, the team have aimed to be more specific about the mental health benefits of engaging in art, developing a method of care 
provision that is measurable and orientated towards the "hard" outcome of discharge. In making a claim for efficacy in the treatment of psychiatric patients with non-clinical methods the service began to translate what it does and was itself transformed by this translation. Up until 2008 Create service-users would arrive at the service and go into one studio and stay there, usually for many years. Descriptions of the service in its early days evoke a sense of a place for in-the-moment unstructured creative activity. As noted above, in late capitalism simply passing time is stigmatized (Thompson, 1967), and ' $[t]$ he present is governed, at almost every scale, as if the future is what matters most' (Adams et al., 2009, p.248). As such this unstructured way of working was changed to increasingly future-orientated practice. The staff realised that letting service-users stay in an art studio for several years did not impart "transferable skills." The model of practice was redesigned in order to focus more on the value of what someone can get out of the art studio; what can be transferred. The new future-orientated practices also enabled the ability to measure the success of the service by counting how long each service-user accessed Create, and what kinds of self-care they engaged in during that time.

\section{The Rotation System}

The new model is known as "the rotation system," which works as follows: A new service-user attends an initial interview with the Occupational Therapist where they discuss what they want to "get out" of their experience at the service. These are written down on a sheet entitled My Aspirations, which is taken with the service-user as they then complete four placements or "rotations" in four separate studios, each lasting twelve weeks (there is scope for continued access after this). At the beginning of each twelve-weeks the service-user and artist-tutor set goals for that rotation together. Each week, the service-user completes a diary which gets them to reflect upon the experience 
of that session, how it made them feel and how they have worked towards meeting their goals. These are reviewed at the end of each rotation. Conversations about discharge generally begin when a service-user is meeting goals, participating fully in the service, and building a liveable life "outside."

The development of the rotation system was facilitated by the Occupational Therapist, Tasha, who was employed to address the problems the artist-tutors had around client discharge rates. In reference to the challenges they faced in implementing the rotation system Tasha told me:

I suppose it was initially quite difficult. Historically, in mental health services as a whole people tended to go into a service and be there for a long time, which put them at risk of becoming dependent and institutionalized, so I suppose that's what I've been working with. And yeah, primarily my role remit was to help move people on (interview 05/11/10)

Here, Tasha draws upon the shameful history of the public mental health system, in which patients were often institutionalized for life, to frame the assertion that "moving on" is a positive thing. Indeed, it can be read as a direct response to the recovery movement's critique of hopelessness in psychiatric practices. However, it can also be understood as a timetable that fosters "change management skills" in service-users. This is enacted through neoliberal discourse in which appropriate subjectivity can be governed through temporalities that determine 'the flow and movement of the body' (Soldatic, 2013, p. 5). The rotation system materializes the experience of change (and its cognate narrative of progress and improvement) as clients conform to its timetable, moving from studio to studio. Concurrently, these practices of temporal-governance act as a measurement for how long a client accesses the service. The aim of this system is ultimately to reduce the economic cost of service-provision whilst demonstrating "effectiveness" through increased discharge rates. 
It has been noted by many authors that a feature of neoliberalism is a reduction in state welfare provision. Welfare is seen to cultivate dependence in its recipients, the antithesis to independent neoliberal subjectivity (see Fraser and valentine, 2008; Holloway and Pimlott-Wilson, 2011; Petersen, 1997; Raco, 2009). For Soldatic (2013) this attempt to reduce perceived dependence upon welfare provision for disabled people has entailed 'a range of moral strategies that situate disability within the new temporal norms of work' (p. 5). This involves increasingly negative representation of disabled people as "scroungers" (Briant et al., 2013; Garthwaite, 2011) in order to 'reinscribe, reimagine and reshape social understandings of the prior welfare state contract and to hide the socio-relations of power deeply embedded within it' (Soldatic, 2013, p. 5). Using the example of the workfare appointment Soldatic (2013) argues that neoliberal governance involves 'temporal discursive markers, which signify the new temporal disciplines of the neoliberal economy' (p. 5: original emphasis). Clock time gains hegemonic status over all other times and rhythms in order to evaluate someone's right to citizenship. This normative temporal subjectivity marginalizes those whose bodies cannot fit with its material practices.

Alan Petersen (1997) argues that under neoliberalism individuals are called upon 'to enter into the process of his or her own self-governance through processes of endless self-examination, self-care and self-improvement' (p. 194). People are asked to demonstrate their moral worth by being "healthy citizens." Being "unhealthy" is to be a burden on the state. In Create, personal accountability and self-regulation towards normative "healthy living" is cultivated via the initial interview, the My Aspirations sheet, regular goal setting and diary writing. These encapsulate the overlapping 
activities of: identifying appropriate hopes and aspirations for the future; improving or acquiring skills for work; the ability to care for one's own emotional wellbeing; and regularly reflecting on how well one is engaging in these practices. For example, new service-users' goals are usually "attending regularly" and "on time" because effective time-management is part of what constitutes self-care and fitness regimes. An appropriate body that is fit and does fit this specific time and place, is one that is regular, punctual, and efficient (Petersen, 1997). Service-users' health and wellbeing is monitored via their attendance and punctuality, and those who need further support in their recovery are highlighted through these temporal markers. In these socio-material practices, recovery entails a particular temporal-subjectivity. The temporalities of aspiration and hope are enacted in the materials of the rotation system.

\section{"My Aspirations"}

An initial interview takes place between Tasha and a potential service-user to specify why that person wants to access Create and ensure this fits with the organisational aims and outcomes. Tasha uses a narrow and overlapping range of questions that signal the ultimate goal of discharge from the outset. She is primarily looking to see if that person will engage in a process that is ultimately about taking responsibility for their own recovery:

They don't have to have any experience of art, but they have to have an interest in art, and an interest in using art as a vehicle to help their recovery. . . . They've got to have a certain amount of ability, cognitive ability, to engage in the processes in Create... I could be interviewing somebody and it's very clear that they're not able at this time to commit to one session a week ... they're not interested in goal setting, they've got very few aspirations for the future, and you might think "mmm, does this person just need a drop-in group?" (Interview 27/07/10)

In the socio-material practices of the initial interview art-making is not a "good" in itself; instead Create is enacted as a place where one goes to learn how to be well through the instrumentalisation of art practices. To be able to realize this aim a service- 
user is required to have commitment, the ability to set goals, and aspirations for the future. The ability to be forward thinking and commit to regular activity is conflated with cognitive ability.

Throughout the interview the reason why that person is there in the first place (sectioning, suicide attempt, a history of trauma or psychiatric intervention) is made absent. Instead, Tasha asks about their prior interests and hopes for the future and how this relates to their wish to access Create. Connecting past interests and future aspirations constructs an anticipatory 'narrative sequence of recovery' (Blackman, 2007, p. 8). As Tasha translates what the service-user says into the language of aspirations, goals, and hopes for the future, she sets 'the conditions of possibility for action in the present' (Adams et al., 2009, p. 249). The initial interview privileges normative temporal subjectivity, transforming the service-user from a chronic mental patient into a neoliberal aspirational citizen (Raco, 2009).

Tasha then takes her notes from the interview and creates the service-user's $M y$ Aspirations sheet, which is organized into two sections: 'My aspirations are...' and 'My hopes for attending Create are...' Framing the service-user's interview responses in this way involves two overlapping temporalities in the service: aspiration and hope. The temporality of aspiration takes life as a whole, listing overall life goals. The word aspiration means 'steadfast longing for a higher goal, earnest desire for something above one' (Online Etymology Dictionary, 2013b). Stemming from the verb aspire, which means 'to breathe,' and the Latin spirare, which means 'spirit,' it draws upon discourses of the soul. It is a strongly moral word; those who aspire are 'steadfast' and 'earnest' in their desire to better themselves (to move 'above' denotes a clear class politics). By employing the language of aspiration, the Create team imbue the service 
with certain values. In the UK, the politics and practices of aspiration can be traced to the neoliberal New Labour government's (1997-2010) emphasis on education as means to generate greater social equality by investment in the nation's "human capital." This new emphasis on education required (working-class) children to aim "higher" than their local context, and the achievements of their parents; to aim towards middle-class values of social and economic independence (Holloway and Pimlott-Wilson, 2011).

Mike Raco (2009) argues that the politics of aspiration are accompanied by a reduction in state welfare. Raco (2009) argues that welfare reform 'focuses on the creation of "aspirational citizens" in deprived areas or communities, individuals, and groups who will "better" themselves and become more like an imagined social "mainstream"' (p.436). Aspirational citizens are imagined to find satisfaction in the pursuit of goals, being entrepreneurial, dynamic, and flexible, and the attainment of material wealth; they are self-responsible, they solve their own problems with minimum state intervention. Indeed, welfare support is understood to limit aspiration and hold people back from pursuing the "natural' human desire to enhance and create material wealth' (Raco, 2009, p. 439). As Holloway \& Pilmott-Wilson (2011) observe the rhetoric of aspiration does little to recognize the reality of entrenched social inequality that continues to grow in spite of the welfare reform that was intended to solve it.

The addition of 'hope' on the My Aspirations sheet can also be read as an individualising imperative for service-users to adopt attitudes of self-responsibility and self-care. For example, Lisa Duggan and José Esteban Muñoz (2009) have noted the political mobilisation of hope in order to 'reward conformity' (p. 276). However, I argue that the co-existence of 'aspiration' with 'hope' highlights tensions between different enactments of recovery in the situated care practices at Create. To hope means 'to 
entertain expectation of something desired' (OED). Raco (2009) argues that the politics of expectation belong to post-war welfare states, and is therefore more about state provision for those most in need. In these times, citizens could expect to be looked after when in distress or poverty. There is a collective 'practice of hope that helps [us] escape from a script in which human existence is reduced ... To want something else, to want beside and beyond the matrix of social controls that is our life in late Capitalism, is to participate in this other form of desiring' (Duggan and Muñoz, 2009, p. 278). I contend that the temporality of collective hope can be found in the socio-material practices of Create alongside neoliberal aspiration.

\section{Milana's Timetable}

Milana explains to me that when she started going to Create she found it almost impossible to attend the weekly textile sessions regularly and on-time:

Yes, while I am in textile class ... I didn't come properly on time and sometimes I miss the class. Because if I'm at home I can't do anything: I can't shower, I can't bath, I can't cook, I can't clean ... So, when I came here my tutor explain me to Tasha, and she make me an appointment, and she give me many advice, and she told me I want to make a timetable to what I'm going to do every day. Then I want to do little by little, not everything every day, one or two things first day, then next day I want to do three things, smaller goals. Then I reached everything, then I'm better, I come back better. Since then I am ok but sometimes struggle, I carry on with these timetables. I wrote a diary, I wrote what I want to do next week; I put and write everything on time, its making me do many things. It's very helpful. (interview 21/09/10)

In a later interview $(05 / 10 / 10)$, she tells me that her difficulty in attending was because hearing voices is very distracting and often deprives her of sleep. In addition, she explained that the neuroleptic medication she is prescribed makes her feel very tired and impedes her ability to walk, as well as making her breathless. Both these factors meant that she often could not get out of bed or contemplate doing such basic tasks as washing, eating or cleaning, never mind making the journey to Create, which involved both walking and catching a bus. Anne, the Textiles tutor, noticed there was a problem: 
Milana did not attend or she was late enough times for it to become a concern, so she referred Milana to Tasha for an assessment. Tasha interviewed Milana to find out why she was having such problems in attending regularly and on-time. This intervention takes the temporal organisation of Milana's everyday existence as both cause and solution. Milana has no set timetable to live her life by; if she had one she would be able to do more with her time.

Tasha aims to change the temporal constitution of Milana's subjective and psychological experiences by bringing something of the service and its approach to Milana at home. Moreover, it is not Tasha or the Create staff's jurisdiction to make decisions about medication, but they do know that stitching can help quieten Milana's voices and so they find creative ways to overcome the disabling effects of her voices and the psychoactive substances she takes. After discerning that the problem that Milana faces is too much unstructured time, Tasha suggests to her that a timetable may be of use. The timetable is positioned as a way to incrementally detail all activity, and to check that tasks will be and have been done: it reshapes the amorphous time of waiting. Milana no longer feels like she is wasting time, nor does she think that she is a waste of time or life. She begins to experience time as a healer. She actively organizes her week in detail, building the amount of things she can do in a day over time: 'little by little' (Milana, interview 21/09/10), and finds that she is 'better' (ibid.) and doing 'many things' (ibid.).

Milana's story emphasizes the interlinking of temporalities and subjectivities. To hold someone in stasis is to reduce agency and reveals the drastic measures someone might take to end the meaningless existence of waiting. Whilst we could critique the rotation system as a temporal form of colonizing neoliberal governance, Milana found 
the tools of timetables and diaries enabling after the distressing feeling of wasting time and being a waste. This temporal ordering made it possible for Milana to find hope in the socio-material practices of stitching and chatting in the Textiles studio at Create. She found ways to experience respite from being overwhelmed by incessant voice-hearing and that she is not a "waste," but rather a skilled embroidery artist who can make beautiful and finely detailed textile work.

\section{Creative Acts of Time-Transcendence}

The staff at Create devised a timetable that is able to measure the health and wellbeing of its service-users according to neoliberal practices of self-care. The initial interview, the goal setting and the diaries all materialize the experience of the service in this way; it conflates recovery with discharge - an outcome rather than an on-going process. However, I have shown that the socio-material practices of Create are not uniformly or ubiquitously neoliberal, but an assemblage of multiple temporalities that are 'conditions of possibility' (Adams, et al., p.249) for complex and diverse subjectivities-in-flux.

Working within the temporal orderings of the rotation system, the artist-tutors are able to discuss what each person needs in order to begin to value themselves again after traumatic experience and attempts to end it all. Tasha responds to signals that Milana cannot make it to the service, where she experiences relaxation and connection with others, by helping her attend Create regularly and on-time. The stitching that Milana does at Create is not necessarily towards the future, but a practice of quietening the distressing voices she hears in the present. The rhythm of stitching beats alongside the repetition of goal setting and diary writing. In this way I argue that recovery in practice at Create entails the embodied rituals and repetitions of art making that enable its 
service-users to engage in 'creative acts of time transcendence' (Adam, 2006, p. 121). For Adam (2006) such rituals are 'collective means to overcome the threat of nonexistence, finitude and transience' (p. 121), which I have argued are often the experience of psychiatric patienthood and/or migrant existence (or, in the case of Milana, both). Through the activity of art-making in the studios, service-users at Create are brought together, they chat, they laugh, and they feel less lonely. They make beautiful things and feel less of a waste. The linearity of Western "machine-time" obscures the complexity of these everyday rhythms of care in practice (Adam, 2006). Thus, the rotation system may be similar to the workfare appointments critiqued by Soldatic (2013), in that they direct the 'flow and movement of bodies' (p. 5) in moralising and normative ways. However, the material-semiotic analysis presented here shows that unlike the example of the workfare appointment, the activity that Create service-users are directed to through the rotation system focuses on agency and collective practices of hope and living "good" lives-in-time.

\section{Conclusion}

The politics of temporality requires close attention for those working for social justice and against inequalities in neoliberal times. Subjectivities and temporalities are multiple and co-constitutive and these are relations of power in which some enactments marginalize others. For example, it has been my contention that the development of the rotation system, whilst conferring some benefits, could entail serious consequences. Sadly, my predictions have been realised, four years after the field work was completed. Having begun to measure service-user time in the service, Create service-staff became obliged to meet targets around discharge based on these statistics. Ultimately, because mental health recovery is an uneven and fragile process, they then failed to meet these 
targets and have lost their funding. This 'failure' in meeting targets belies their commitment to service-users' wellbeing over organisational criteria. Yet the irony is that in the current context this ethics of care is untenable.

Targets set for discharge do not recognize the complexity of recovery in its temporality. Recovery takes time; it is a struggle for a "good life-in-time." Attempts to reduce service provision in the name of recovery are at the extreme opposite to the previous models of institutional care in which patients were incarcerated for life. One of the significant potentials for harm in neoliberal practices of temporal-governance is that these create conditions under which services must do more with less funding and therefore less time. "Good" care cannot flourish in this context. People are afforded less time to rebuild lives and impelled to conform to normative temporal orderings that are likely to be impossible.

\section{Endnotes}

1. Research in this area show that the history of recovery is much longer than its use by mental health activists from 1970s onwards (see for example Jacobson, 2004). However, in its current iteration its activist origin is the story most often told.

2. All names are pseudonyms and some details have been changed to preserve research participant anonymity.

3. The exact details of this separation were not covered during our interviews; however, it is clear that it was not a separation that they chose.

4. Hearing voices is not universally a distressing and debilitating experience for everyone, as co-founders of the Hearing Voices Network, Patsy Hage, Marius Romme and Sandra Escher found in their research (Hornstein, 2009). 
5. This is one reading of diagnosis as a singular, decisive and universally violent act. However, other people have sought a diagnosis in order that they might access services, support make sense of their experiences.

\section{References}

Adam, B. (2006) Time. Theory Culture \& Society 23 (2-3): 119-126.

Adams, V., Murphy, M., and Clarke, A.E. (2009) Anticipation: Technoscience, life, affect, temporality. Subjectivity 28: 246-265.

Bayart, J.-F. (2007) Global Subjects: A Political Critique of Globalization. Cambridge: Polity Press.

Bentall, R.P. (2004) Madness Explained: Psychosis and Human Nature. London: Penguin. Blackman, L. (2007) Psychiatric Culture and Bodies of Resistance. Body \& Society 13: 123.

Blackman, L., Cromby, J., Hook, D., Papadopoulos, D., and Walkerdine, V. (2008) Creating Subjectivities. Subjectivity 22: 1-27.

Bracken, P.J. and Thomas, P. (2006) Postpsychiatry: Mental Health in a Postmodern World. Oxford, New York: OUP Oxford.

Briant, E., Watson, N., and Philo, G., 2013. Reporting disability in the age of austerity: the changing face of media representation of disability and disabled people in the United Kingdom and the creation of new "folk devils". Disability \& Society 28: 874-889.

Campbell, P. (1996) Challenging loss of power. In: J. Read and J. Reynolds (eds.) Speaking Our Minds: An Anthology of Personal Experiences of Mental Distress and Its Consequences. Basingstoke: Macmillan/Palgrave, pp. 56-62.

Chamberlin, J. ([1977] 1988). On Our Own: Patient-Controlled Alternatives to the Mental Health System. London: MIND Publications.

Champ, S. (1999). A most precious thread. In: P. Barker, Campbell, P. and B. Davidson (eds.) From the Ashes of Experience: Reflections on Madness, Survival and Growth. London: Wiley-Blackwell, pp. 113-126.

Clay, S. (1999) Madness and reality. In: P. Barker, Campbell, P. and B. Davidson (eds.) From the Ashes of Experience: Reflections on Madness, Survival and Growth. London: Wiley-Blackwell, pp. 16-36.

Craig, T.K.J. (2008) Recovery: Say what you mean and mean what you say. Journal of Mental Health 17: 125-128. 
Deegan, P. E. (1994). Recovery: The Lived Experience of Rehabilitation.

http://myweb.polyu.edu.hk/ ssmliang/web\%20info/newlifereocovery/Deegan\%2019 94\%281988\%29.pdf, accessed 14 April 2011.

Duggan, L. and Muñoz, J.E. (2009) Hope and hopelessness: A dialogue. Women \& Performance: a journal of feminist theory 19: 275-283.

Edelman, L. (2004) No Future: Queer Theory and the Death Drive. Durham: Duke University Press.

Faculty of Public Health (2008) The health needs of asylum seekers: Briefing statement. http://www.fph.org.uk/uploads/bs_aslym_seeker_health.pdf, accessed 30th April 2015.

Fraser, S. and valentine, k. (2008) Substance and Substitution: Methadone Subjects in Liberal Societies: Methadone Subjects in Liberal Society, Basingstoke, New York: Palgrave.

Frese, F.J. and Davis, W.W. (1997) The consumer-survivor movement, recovery, and consumer professionals. Professional Psychology: Research and Practice 28: 243-245.

Garthwaite, K., 2011. “The language of shirkers and scroungers?” Talking about illness, disability and coalition welfare reform. Disability \& Society 26: 369-372.

Geertz, C. (1995). After the Fact: Two Countries, Four Decades, One Anthropologist. Cambridge: Harvard University Press.

Haraway, D.J. (1997) Modest witness@second millenium: femaleMan meets OncoMouse: feminism and technoscience. New York, London: Routledge.

Hornstein, G. A. (2009) Agnes's Jacket: A Psychologist's Search for the Meanings of Madness. New York: Rodale.

Holloway, S.L. and Pimlott-Wilson, H. (2011) The politics of aspiration: neo-liberal education policy, "low" parental aspirations, and primary school Extended Services in disadvantaged communities. Children \& Geographies 9: 79-94.

Howells, A. and Voronka, J. (2012) Introduction: the politics of resilience and recovery in mental health care. Studies in Social Justice 6 (1): 1-7.

Jacobson, N. (2004) In Recovery: The Making of Mental Health Policy. Nashville:

Vanderbilt University Press.

Jeffrey, C. (2008) Waiting. Environment and Planning D: Society and Space 26: 954 - 958.

Mol, A. (2002) The Body Multiple: Ontology in Medical Practice. Durham, London: Duke University Press.

Morrow, M. (2013). Recovery: progressive paradigm or neoliberal smokescreen? In B.A. LeFrancois, R. Menzies \& G. Reaume Mad Matters: A Critical Reader in Canadian Mad Studies (pp.323-333). Toronto: Canadian Scholar's Press. 
Online Etymology Dictionary (2013b) Aspiration.

http://www.etymonline.com/index.php?term=aspiration\&allowed_in_frame=0, accessed 24 November 2013.

Online Etymology Dictionary (2013c) Aspire.

http://www.etymonline.com/index.php?term=aspire\&allowed_in_frame $=0$, accessed 24 November 2013.

Online Etymology Dictionary (2013d) Spirit.

http://www.etymonline.com/index.php?term=spirit\&allowed_in_frame=0, accessed 24 November 2013.

Petersen, A. (1997) Risk, governance and the new public health. In: R. Bunton and A. Petersen (eds.) Foucault, Health and Medicine. London, New York: Routledge, pp. 189206.

Pilgrim, D. (2009) Recovery from mental Health Problems: Scratching The Surface Without Ethnography. Journal of Social Work Practice 23: 475-487.

Poole, J. (2011). Behind the Rhetoric: Mental Health Recovery in Ontario. Winnipeg: Fernwood Publishing.

Raco, M. (2009) From expectations to aspirations: State modernisation, urban policy, and the existential politics of welfare in the UK. Political Geography 28: 436-444.

Refugee Council, 2013. The Facts about Asylum.

http://www.refugeecouncil.org.uk/policy_research/the_truth_about_asylum/facts_abo ut_asylum_-_page_5, accessed 6 February 2012.

Repper, J., and Perkins, R., 2003. Social inclusion and Recovery: A Model for Mental Health Practice. Edinburgh: Baillière Tindall.

Sedgwick, P. (1987). Psycho Politics. London: Pluto Press.

Slade, M., Amering, M. and Oades, L. (2008) Recovery: an international perspective. Epidemiology and Psychiatric Sciences 17: 128-137.

Soldatic, K. (2013) Appointment Time: Disability and Neoliberal Workfare Temporalities. Critical Sociology 39: 405-419.

Thompson, E.P. (1967) Time, Work-Discipline, and Industrial Capitalism. Past \& Present: 56-97.

Turner-Crowson, J. and Wallcraft, J. (2002) The recovery vision for mental health services and research: A British perspective. Psychiatric Rehabilitation Journal 25: 245254.

Tyler, I. (2013) Revolting Subjects: Social Abjection and Resistance in Neoliberal Britain. London: Zed. 
Zerubavel, E. (1982) The Standardization of Time: A Sociohistorical Perspective. American Journal of Sociology 88: 1-23.

Zerubavel, E. (1987) The Language of Time: Toward a Semiotics of Temporality. The Sociological Quarterly 28: 343-356.

\section{Acknowledgements}

I am grateful to the staff and service-users of Create who participated in the research (funded by the ESRC - Ref: ES/G018529/1). Imogen Tyler, Celia Roberts, Vicky Singleton, Helen Spandler, Monica Greco, and Nat Gill for their valuable feedback, and the anonymous reviewers for their helpful comments.

Word Count: 7717 